lary blastic crisis of chronic myelogenous leukemia: report of a case. Blut 1989;59:458-9.

7 Molho P, Grange MJ, Gueris J. Hypercalcaemia in chronic myeloid leukemia: evidence for excessive parathyroid hormone secretion. Nouv Rev Fr Haematol 1985;27:189-92. 8 Attar E, Prokocimer M, Januszewicz E, Theodor E. Hyper8 Attar E, Prokocimer M, Januszewicz E, Theodor E. Hyperof chronic myeloid leukemia. Acta Haematol 1988;79:211-2.
9 Walter M, Greenberg BR. Hypercalcaemia in the accelerated phase of chronic myeloid leukemia. Cancer 1980;46: 1174-8.

10 Hasselbalch H, Birgens HS, Geisler C, Hansen NE. Hypercalcaemia in the accelerated phase of chronic myeloid leukemia. No relationship to the phenotype of the blast cells. Scand $\mathcal{F}$ Haematol 1985;35:333-8.

\title{
Renal calculi following superior mesenteric artery occlusion
}

\author{
L Ranganath, S R Gould, P F Goddard
}

A 48-year-old woman developed an occlusion of the superior mesenteric artery resulting in infarction of the jejunum, ileum and proximal colon up to the splenic flexure. She underwent extensive small intestinal resection followed by a jejunocolic anastomosis; the residual jejunal length was $35 \mathrm{~cm}$. She was morbidly obese prior to intestinal resection (weight $102 \mathrm{~kg}$; BMI 45.7) and steadily lost weight following the surgery. Initially, she experienced marked diarrhoea post-resection; this improved until she was experiencing four to eight bowel movements daily.

She re-presented two years later with painless haematuria when she was found to have multiple calculi in the left kidney. She underwent lithotripsy following which a temporary renal stent was inserted for six months. Baseline serum electrolytes, calcium and liver profiles as well as 24-hour urine calcium and urate excretion at this time were normal. She had significant renal impairment with subnormal creatinine clearance as well as raised serum creatinine and urea following this episode, which resolved partially. She was advised to go on a low-calcium diet.

She was re-evaluated three years following intestinal resection when her body weight was 53.5 $\mathrm{kg}$ (BMI 23.6). She continued to have frequent bowel movements and was almost certainly mal-

Epsom General Hospital, Epsom, KT18 7EG, UK Department of Chemical Pathology

L Ranganath

P F Goddard

Department of

Medicine

S R Gould

Accepted 19 November 1997 absorbing. She had noticed foul smelling and pale faeces which were difficult to flush. Cholestyramine therapy had no effect on the diarrhoea although some relief was obtained with codeine phosphate.

\section{Questions}

1 What is the cause of the renal calculi in this woman?

2 Comment on the dietary advice she was following at the time of presentation.

3 What further investigations would you perform?

4 What further therapy would you consider? 


\section{Answers}

\section{QUESTION 1}

In a patient with short bowel syndrome with restoration of continuity between jejunum and colon, presenting with renal calculi, a diagnosis of enteric hyperoxaluria must always be considered.

\section{OUESTION 2}

She had been advised to follow a low-calcium diet since the vast majority of patients with renal calculi have hypercalciuria. This may, however, worsen oxaluria in those with enteric hyperoxaluria.

\section{QUESTION 3}

Urinary oxalate excretion studies during dietary modification and calcium supplementation.

QUESTION 4

The following therapies should be considered: calcium supplementation to reduce oxalate absorption in the gut, low oxalate diet, and low fat diet, or pyridoxine therapy to reduce endogenous oxalate generation.

Investigations during the latest visit were: serum urea, creatinine, ferritin, B12 and folate were $6.3 \mathrm{mmol} / 1$ (reference range 2.3-6.3), 154 $\mu \mathrm{mol} / \mathrm{l}$ (50-130), $26 \mathrm{ng} / \mathrm{ml}$ (10-300), 198 $\mathrm{pg} / \mathrm{ml}(150-950)$ and $7.5 \mathrm{ng} / \mathrm{ml}(2.0-14.0)$, respectively. 24-Hour urine collections revealed a small urine volume as well as oxaluria confirming the diagnosis of enteric hyperoxaluria secondary to the short bowel syndrome. Cholestyramine did not reduce oxalate excretion but supplementary oral calcium ( $1 \mathrm{~g}$ twice daily) normalised urinary oxalate excretion without any increase in calciuria (figure, table).

Following the diagnosis of enteric hyperoxaluria, she was advised to follow a normal calcium, low oxalate and low fat diet and was commenced on supplementary oral calcium $1 \mathrm{~g}$ bid. Additional oral therapy with pyridoxine $50 \mathrm{mg}$ tid and alkaline citrate solution was also begun. She experienced a further episode of renal colic at the age of 51 years and underwent lithotripsy for a stone in the left kidney. She had discontinued oral calcium having been unable to tolerate chewable calcium (Calcichew) or effervescent calcium gluconate and the 24-hour urine oxalate excretion was again very high. She has since been able to tolerate oral calcium gluconate non-effervescent tablets at a dose of $600 \mathrm{mg}$ tid. Her renal function remains stable and she has not experienced any further renal colic.

Dietary calcium complexes luminal oxalate and limits their absorption. When excess faecal fats are present secondary to steatorrhoea,

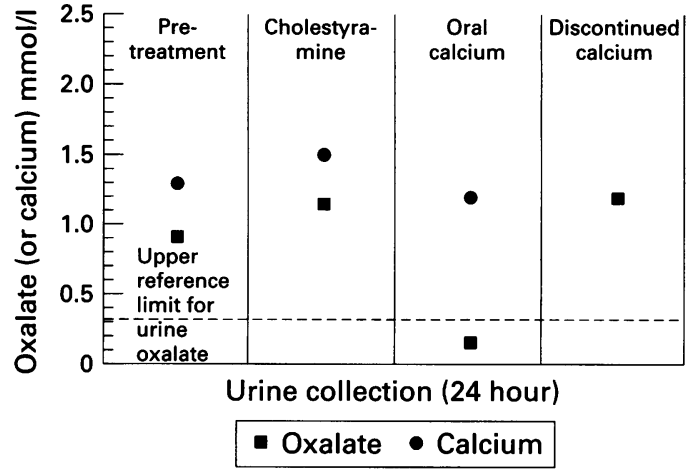

Figure Urinary oxalate and calcium excretion prior to and after therapy with cholestyramine and oral calcium supplementation

unabsorbed fatty acids compete with oxalate for calcium, leading to greater oxalate absorption. ${ }^{1}$ This oxalate absorption occurs in the colon whose permeability to oxalate is increased in the presence of unabsorbed bile salts as well as long chain fatty acids ${ }^{2}$; cholestyramine has been shown to reduce oxaluria by chelating bile salts ${ }^{3}$ but had no effect in our patient. A higher fat intake, to stabilise body weight, aggravated steatorrhoea in our patient, while the low calcium diet followed prior to detection of oxaluria could have encouraged greater colonic oxalate absorption. Oral calcium $2 \mathrm{~g}$ daily 'normalised' her oxaluria indicating its importance, as described in previous studies. ${ }^{4}$ Organic marine hydrocolloids (which can be given orally as therapy), in which calcium is firmly bound to the colloid making it is unavailable for absorption, not only bind oxalate but also reduce the risk of hypercalciuria. $^{4-6}$

Although the effectiveness of pyridoxine therapy in reducing endogenous oxalate production has not been convincingly shown, ${ }^{7}$ our patient was treated with pyridoxine at a dose of $150 \mathrm{mg}$ daily. However, when she discontinued oral calcium, at a time when she was on a low oxalate and fat diet as well as on pyridoxine and alkaline potassium citrate (which indirectly increases urinary citrate and thus inhibits stone formation), urine oxalate excretion returned to previously high levels, indicating that colonic oxalate absorption was the dominant cause of oxaluria in this patient. This also indicated that calcium supplementation was perhaps the most important oxaluria-reducing therapeutic modality in this woman.

The excretion of oxalate, a strong dicarboxylic acid, is entirely renal. ${ }^{8}$ Hyperoxaluria leads to oxalate deposition and renal impairment, as

Table Laboratory investigations (in 24 hour urine collections)

\begin{tabular}{|c|c|c|c|c|c|c|c|}
\hline Collection & Treatment & $\begin{array}{l}\text { Volume } \\
(\mathrm{ml})\end{array}$ & $\begin{array}{l}\text { Creatinine } \\
\text { clearance } \\
\text { (ml/min) }\end{array}$ & $\begin{array}{l}\text { Urate } \\
\text { (mmol) }\end{array}$ & $\begin{array}{l}\text { Calcium } \\
\text { (mmol) }\end{array}$ & $\begin{array}{l}\text { Phosphate } \\
\text { (mmol) }\end{array}$ & $\begin{array}{l}\text { Oxalate } \\
\text { (mmol) }\end{array}$ \\
\hline 1 & None & 600 & 38 & 0.6 & 1.3 & 10.1 & 0.91 \\
\hline 2 & cholestyramine 2 sachets daily & 900 & 46 & 1.4 & 1.5 & 20.2 & 1.15 \\
\hline 3 & calcium $2 \mathrm{~g}$ daily & 1000 & 43 & 1.4 & 1.2 & 12.3 & 0.16 \\
\hline 4 & calcium discontinued & - & - & - & - & - & 1.2 \\
\hline Reference range & & - & $70-120$ & $1.5-4.5$ & $2.5-7.5$ & $11-32$ & $<0.32$ \\
\hline
\end{tabular}


was seen in our patient, but renal impairment in turn prevents oxalate excretion, establishing a self-perpetuating cycle. It is therefore imperative that oxalate absorption in the gut be maximally inhibited.

1 Chadwick VS, Modha K, Dowling RH. Mechanism for hyperoxaluria in patients with ileal dysfunction. $N$ Engl hyperoxaluria in patient

2 Dobbins JW, Binder HJ. Effect of bile salts and fatty acids on the colonic absorption of oxalate. Gastroenterology 1976;70 1096-1100.

3 Smith LH, Fromm H, Hofmann AF. Acquired hyperoxaluria, nephrolithiasis and intestinal disease. Description of a syndrome. $N$ Engl $\mathcal{F}$ Med 1972;286:1371-5.

4 Hylander E, Jarnum S, Nelsen $K$. Calcium treatment of enteric hyperoxaluria after JIB for morbid obesity. Scand $\mathcal{F}$ Gastoenterol 1980;15:349-52.

\section{Final diagnosis}

Enteric hyperoxaluria.

Keywords: renal calculi; short bowel syndrome; enteric hyperoxaluria; calcium

5 Barilla DE, Notz C, Kennedy D, Pak CYC. Oxalate absorption and excretion. Am 7 Med 1978;64:579-85.

6 Lindsjo M, Fellstrom B, Ljunghall S, Wikstrom B, Danielson BG. Treatment of enteric hyperoxaluria with calcium-containing organic marine hydrocolloid. Lance 1989;ii:701-4.

7 Lyon ES, Borden TA, Ellis JE, Vermeulen CW. Calcium oxalate lithiasis produced by pyridoxine deficiency and inhibition by high magnesium diets. Invest Urol 1966;4:133-42.

8 Woolfson RG, Mansell MA. Hyperoxaluria and renal calculi. Postgrad Med F 1994;70:695-8.

\title{
Hypokalaemic alkalosis
}

\author{
N Kessaris, K Shotliff, S S Nussey
}

A 68-year-old woman was admitted with a 3-week history of swelling of the head and neck, breathlessness, anorexia, and weight loss. She had been previously well and, apart from long-standing systemic hypertension, her medical history had been unremarkable. A life-long smoker, she also enjoyed half a litre of spirits a day and had been taking enalapril for 3 years.

On examination, stigmata of chronic liver disease were noted and her face appeared swollen with fullness in the right supraclavicular fossa. Cardiovascular examination was unremarkable apart from a blood pressure of $165 / 85 \mathrm{mmHg}$. Abdominal examination revealed multiple striae and hepatosplenomegaly.

Investigations of note included a haemoglobin of $10.6 \mathrm{~g} / \mathrm{dl}$ and a potassium of $1.8 \mathrm{mmol} / \mathrm{l}$. Urea and creatinine were within normal limits. Arterial blood gases showed a pH of 7.58 and bicarbonate of $53.1 \mathrm{mmol} / 1$. Alkaline phosphatase was $130 \mathrm{U} / 1$ and $\gamma$-glutamyl transferase $785 \mathrm{U} / \mathrm{l}$. Chest $\mathrm{X}$-ray showed widening of the superior mediastinum. Serum cortisol was $>2000 \mathrm{nmol} / 1$ and urine cortisol was $>9000 \mathrm{nmol} / 24 \mathrm{~h}$ (normal $60-250 \mathrm{nmol} / 24 \mathrm{~h}$ ). Plasma adrenocorticotropin (ACTH) was $148 \mathrm{ng} / 1$ (0-50 ng/l) and ACTH precursors $>1500 \mathrm{pmol} / 1$ (5-40 pmol/l). An $09.00 \mathrm{~h}$ serum cortisol after $2 \mathrm{mg}$ dexamethasone administered orally at $23.00 \mathrm{~h}$ the previous night was $>2000$ $\mathrm{nmol} / \mathrm{l}$. Investigations with higher doses of dexamethasone failed because of inability to swallow the medication. Angiotensin-converting enzyme was not elevated.

Barium swallow showed diffuse mucosal irregularity affecting the oesophagus from the level of C7 down to the aortic arch. Ultrasound of the abdomen revealed liver metastases. Endoscopy showed frank nodular oesophageal carcinoma from $25 \mathrm{~cm}$ to $35 \mathrm{~cm}$. Histologically this was an anaplastic small-cell carcinoma, which stained positive for Grimelius and chromogranin A but immunostaining for ACTH was negative. She was started on treatment but her condition deteriorated and she died four days later.

\section{Questions}

1 What is the diagnosis?

2 Suggest two other causes for the acid-base disturbance. Nussey

3 What treatment would you have started this patient on ? 